\title{
Hadal trenches are dynamic hotspots for early diagenesis in the deep sea
}

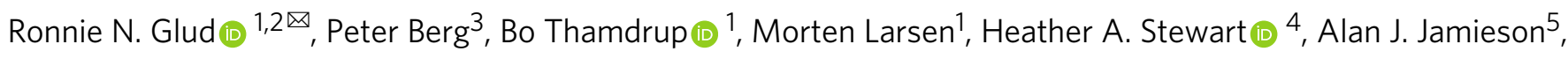
Anni Glud', Kazumasa Oguri, ${ }^{1,6}$, Hamed Sanei (10 7, Ashley A. Rowden ${ }^{8,9}$ \& Frank Wenzhöfer (1) 1,10,11

The deepest part of the global ocean, hadal trenches, are considered to act as depocenters for organic material. Relatively high microbial activity has been demonstrated in the deepest sections of some hadal trenches, but the deposition dynamics are thought to be spatially and temporally variable. Here, we explore sediment characteristics and in-situ benthic oxygen uptake along two trenches with contrasting surface primary productivity: the Kermadec and Atacama trenches. We find that benthic oxygen consumption varies by a factor of about 10 between hadal sites but is in all cases intensified relative to adjacent abyssal plains. The benthic oxygen uptake of the two trench regions reflects the difference in surface production, whereas variations within each trench are modulated by local deposition dynamics. Respiratory activity correlates with the sedimentary inventories of organic carbon and phytodetrital material. We argue that hadal trenches represent deep sea hotspots for early diagenesis and are more diverse and dynamic environments than previously recognized.

\footnotetext{
${ }^{1}$ Department of Biology, University of Southern Denmark, Nordcee and HADAL, 5230 Odense M, Denmark. ${ }^{2}$ Tokyo University of Marine Science and Technology, 4-5-7 Konan, Minato-ku, Tokyo 108-8477, Japan. ${ }^{3}$ Department of Environmental Sciences, University of Virginia, 291 McCormick Road, Charlottesville, VA 22904-4123, USA. ${ }^{4}$ British Geological Survey, Lyell Center, Research Avenue South, Edinburgh EH14 4AP, UK. 5 School of Natural and Environmental Sciences, Newcastle University, Newcastle Upon Tyne NE1 7RU, UK. ${ }^{6}$ Research Institute for Global Change, Japan Agency for Marine-Earth Science and Technology (JAMSTEC), 2-15 Natsushima-cho, Yokosuka, Kanagawa 237-0061, Japan. ${ }^{7}$ Department of Geoscience, Aarhus University, HøeghGuldbergs gade 2, 8000 Aarhus C, Denmark. ${ }^{8}$ National Institute of Water \& Atmosphere Research (NIWA), Private Bag, 14901 Wellington, New Zealand. ${ }^{9}$ Victoria University of Wellington, PO Box 600Wellington, New Zealand. ${ }^{10}$ HGF-MPG Group for Deep Sea Ecology and Technology, Alfred-WegenerInstitute Helmholtz-Center for Polar and Marine Research, 27570 Bremerhaven, Germany. ${ }^{11}$ Max Planck Institute for Marine Microbiology, 28358 Bremen, Germany. ${ }^{凶}$ email: rnglud@biology.sdu.dk
} 
$\mathrm{T}$ he 27 hadal trenches encompassing the depth range of 6000 to $11,000 \mathrm{~m}$ stretch along the tectonic subduction zones and represent the deepest parts of the global ocean ${ }^{1}$. Temperature, $\mathrm{O}_{2}$ availability, and current velocities in hadal settings resemble conditions in other deep sea environments, but the extreme hydrostatic pressure and geographic isolation favor lower diversity and endemism among piezophilic communities ${ }^{2}$. Seismic-driven mass-wasting, downslope funneling, and fluid dynamics appear to enhance local deposition, and hadal trenches have been argued to represent important depocenters for organic matter ${ }^{3-9}$. Reports on elevated abundance of prokaryotes, infauna, and scavenging fauna in the deepest parts of trenches relative to the adjacent abyssal plains also suggest that enhanced deposition of organic matter potentially sustains a higher biological activity despite the extreme settings ${ }^{8,10-14}$. However, sampling at hadal depths is technically challenging and the few existing studies mainly target the deepest sedimentary basins of trenches. Furthermore, reliable sample recovery from great depth can be confounded by severe artefacts related to shifts in hydrostatic pressure and transient heating, which may compromise the assessment of biological activity and early diagenesis in recovered sediment ${ }^{15-17}$. Conversely, in situ quantification of the benthic $\mathrm{O}_{2}$ consumption rate is considered a robust proxy of biological activity and benthic carbon mineralization in deep sea settings $^{18}$.

In situ measurements of benthic $\mathrm{O}_{2}$ uptake have demonstrated that rates of benthic mineralization of organic material gradually decrease by 2-3 orders of magnitude from the coastal oceans to $6000 \mathrm{~m}$ water depth on abyssal plains ${ }^{18}$. Yet recent in situ measurements in the deepest sedimentary basins of trenches suggest that this pattern might be reversed in the hadal realm, and that intensified deposition of organic matter could enhance biological activity and benthic carbon mineralization at these sites $13,19,20$. While these studies together only covered the deepest points in each of five hadal trenches, there is increasing evidence that varied hadal seascapes and local dynamics may result in highly variable seafloor conditions across the depths of a trench as well as along the trench axis and that the very deepest point may not reflect the conditions of the trench as a whole ${ }^{21}$. Thus, investigations of within-trench variability are key for understanding element cycling and early diagenesis in these unique environments.

To explore availability and mineralization of organic carbon along two contrasting hadal systems, we visited the Kermadec and Atacama trenches during 24 November-14 December; 2017 and 2 March-2 April; 2018, respectively (Fig. 1a). Five hadal sites were targeted along a $483 \mathrm{~km}$ transect in the Kermadec Trench (depth range $9300-10,010 \mathrm{~m}$ ) together with one abyssal reference site (depth $6080 \mathrm{~m}$ ), while six hadal sites along a $445 \mathrm{~km}$ transect (depth range 7720-8085 m) and two abyssal reference sites (depths $4050 \mathrm{~m}$ and $5500 \mathrm{~m}$ ) were investigated in the Atacama Trench region (Table 1, Fig. 1b, c). The estimated surface primary production in the Kermadec Trench region is $\sim 400 \mathrm{mg} \mathrm{C} \mathrm{m}^{-2} \mathrm{~d}^{-1}$, while the value for the Atacama trench region amounts to $\sim 900$ $\mathrm{mg} \mathrm{C} \mathrm{m}{ }^{-2} \mathrm{~d}^{-1}$ (Table 1).

\section{Results and discussion}

At each site, we deployed two autonomous instruments; a "Reiver" for probing and imaging the sediment surface and a "HadalProfiler Lander" for measuring the benthic $\mathrm{O}_{2}$ distribution. The initial sediment probing with the Reiver enabled us to assess whether the seafloor was appropriate for subsequent lander deployments and sediment sampling (Supplementary Fig. S1). The Hadal-Profiler Lander was equipped with a transecting array of $\mathrm{O}_{2}$ microsensors which enabled measurements of multiple sets of $\mathrm{O}_{2}$ microprofiles during the 15-24-h long deployments ${ }^{13,22}$. The $\mathrm{O}_{2}$ microprofiles were used to calculate the diffusion mediated $\mathrm{O}_{2}$ uptake (DOU) and the depth distribution of the volume specific $\mathrm{O}_{2}$ consumption rate ${ }^{23}$ (see "Methods summary"). While the DOU only represent about $50 \%$ of the total $\mathrm{O}_{2}$ uptake in fauna-rich coastal sediments, parallel measurements down to $4000 \mathrm{~m}$ depth have shown that the total and the diffusive mediated $\mathrm{O}_{2}$ consumption rates converge with increasing water depth as macrofauna biomass attenuates, and thus rates of these two measures become statistically indifferent at deep sea settings ${ }^{18}$. Therefore, DOU calculated from microprofiles generally provide a robust rate measurement of sediment community respiration in deep sea environments. Intact sediment cores were recovered by a multi-corer ${ }^{24}$, by an autonomous coring lander, or sub-sampled from a box-corer ${ }^{25}$ as indicated in Table 1. It is not trivial to recover intact sediment from hadal depths, and here we only report on sediment cores that were recovered with an apparently intact sediment surface and clear overlying water. The sediment cores were sectioned and preserved for a wide range of geological, biogeochemical, biological, and microbial investigations. Here we report on the sediment porosity, total organic carbon (TOC \%), and phytodetrital pigment concentrations (see "Method summary").

We obtained a total of 206 microprofiles in the two trench regions, ranging from 6 to 39 microprofiles per site depending on breakage or malfunctions of the applied microelectrodes. The average and the median of the profile numbers per site were 14.7 and 11 , respectively. Some $\mathrm{O}_{2}$ microprofiles were clearly disturbed by obstacles; infauna, pumice, nodules or small stones that were encountered sporadically in the recovered sediment. Such encounters resulted in noisy and disturbed $\mathrm{O}_{2}$ signals, and a few occasional subsurface $\mathrm{O}_{2}$ concentration peaks that could imply bioirrigation. Such "disturbed" profiles were not included in the quantification of the benthic $\mathrm{O}_{2}$ consumption rates (Table 2).

In the Kermadec Trench region, measurements at the abyssal site $\mathrm{K} 7$ off the trench axis, exhibited an $\mathrm{O}_{2}$ penetration depth (OPD), that exceeded the maximum measuring depth of $\sim 20 \mathrm{~cm}$, and the derived averaged DOU $\left(152 \pm 22 \mu \mathrm{mol} \mathrm{m}^{-2} \mathrm{~d}^{-1}\right)$ was the lowest rate encountered at any of the 14 sites visited in the two trench regions (Fig. 2 and Table 2). All sites along the Kermadec Trench axis exhibited steeper $\mathrm{O}_{2}$ attenuation, shallower OPD and a higher DOU than encountered at abyssal site K7. There was, however, considerable difference in activity levels along the trench axis with values ranging from of $193 \pm 21 \mu \mathrm{mol} \mathrm{m}{ }^{-2} \mathrm{~d}^{-1}$ at $\mathrm{K} 4$ to $668 \pm 83 \mu \mathrm{mol} \mathrm{m} \mathrm{m}^{-2} \mathrm{~d}^{-1}$ at K2 (Table 2). The volume specific $\mathrm{O}_{2}$ consumption rate was generally intensified close to the sediment surface and to a lesser extent at the oxic-anoxic interface. This pattern is typically ascribed to elevated lability of organic carbon at the sediment surface and intensified oxidation of reduced inorganic constituents $\left(\mathrm{Fe}^{2+}, \mathrm{Mn}^{2+}, \mathrm{NH}_{4}{ }^{+}, \mathrm{H}_{2} \mathrm{~S}, \mathrm{FeS}\right)$ close to the oxic-anoxic interface - solutes and solids being produced by deeper anaerobic mineralization processes ${ }^{26}$. The intensified activity at the sediment surface could imply that lability of the organic material is a key-driver for the overall aerobic activity in these settings. The relative amount of $\mathrm{O}_{2}$ consumed in the sediment layers close to the oxic-anoxic interface in the Kermadec Trench region ranged between 5\% and 23\% (Table 2).

In the Atacama Trench region, we visited two abyssal reference sites one at either side of the trench axis. Site A7, at the oceanward side of the trench, had an OPD $>20.0 \mathrm{~cm}$ and a DOU of $355 \pm 31 \mu \mathrm{mol} \mathrm{m} \mathrm{m}^{-2} \mathrm{~d}^{-1}$, while A9 at the landward side of the trench had an $\mathrm{O}_{2}$ penetration of $6.2 \pm 0.5 \mathrm{~cm}$ and a DOU of $687 \pm$ $101 \mu \mathrm{mol} \mathrm{m} \mathrm{m}^{-2} \mathrm{~d}^{-1}$ (Fig. 2 and Table 2). Thus, the landward reference site being closer to the continent and the productive coastal ocean had - as expected - higher benthic $\mathrm{O}_{2}$ consumption 


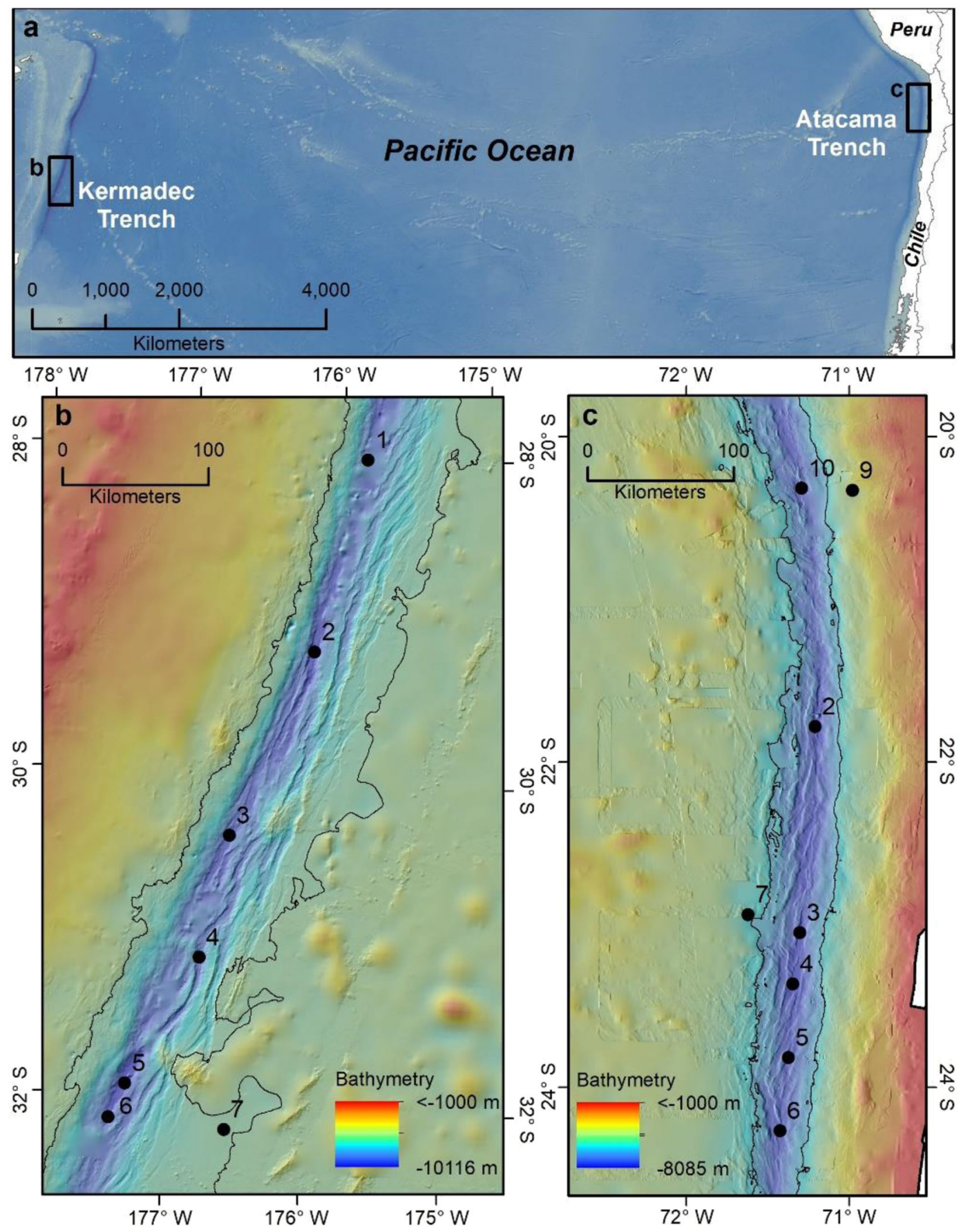

Fig. 1 Study areas in the Kermadec Trench and the Atacama Trench regions in the Pacific Ocean. Detailed bathymetrys with specific sampling sites in the two respective trenches; Kermadec Trench (b) and Atacama Trench (c). The sites were visited during two cruises with RV Tangaroa (TAN1711, 2017) and RV Sonne (SO261, 2018), respectively. Bathymetry data were obtained from the Global Multi-Resolution Topography Synthesis (Ryan et al. ${ }^{41}$; see also supplementary references). Black line in $\mathbf{b}$ and $\mathbf{c}$ indicates the $6000 \mathrm{~m}$ depth contour. Figure; Copyright British Geological Survey ${ }^{\circledR}$ UKRI 2020.

rates. Still, as in the Kermadec Trench, all hadal sites along the Atacama trench expressed markedly higher activity than the abyssal reference sites (Fig. 2 and Table 2) and the volume specific activity attenuated steeply below the surface and typically exhibited a secondary peak close to the oxic-anoxic interface. The $\mathrm{O}_{2}$ concentration in the bottom water of the Atacama Trench region was somewhat lower $\left(\sim 160 \mu \mathrm{mol} \mathrm{L} \mathrm{L}^{-1}\right)$ compared to that of the Kermadec Trench region $\left(\sim 210 \mu \mathrm{mol} \mathrm{L}{ }^{-1}\right)$, but the Atacama Trench DOU rates clearly exceeded the values from the latter (Table 2). In fact, the resolved OPD and DOU in the $\sim 8000$ $\mathrm{m}$ deep Atacama Trench aligned with values encountered previously in sediments from continental shelves and slopes ${ }^{18}$ (Supplementary Fig. S2). The empirical relationship between the resolved DOU and OPD aligned with observations from other ocean realms, and the relation was used to assess the OPD for the least active sites (Table 2 and Supplementary Fig. S2).

Thus, for both study regions, the benthic $\mathrm{O}_{2}$ consumption rates observed at all hadal sites exceed the values encountered at neighboring abyssal plain sites, and our results demonstrate that hadal trenches represent sites of intensified early diagenesis in the deep sea. However, the DOU along both trench axes also exhibited a high degree of variability (Fig. 2, Table 2). Previous 
Table 1 Positions and water depths at the investigated sites in the Kermadec (K) and the Atacama (A) trench regions.

\begin{tabular}{|c|c|c|c|c|c|}
\hline Site & Latitude & Longitude & Depth (m) & $\mathrm{NPP}\left(\mathrm{mg} C \mathrm{~m}^{-2} \mathrm{~d}^{-1}\right)$ & Coring \\
\hline K2 & $29^{\circ} 13.70^{\prime} \mathrm{S}$ & $176^{\circ} 07.00^{\prime} \mathrm{W}$ & 9700 & 340 & - \\
\hline K3 & $30^{\circ} 22.84^{\prime} \mathrm{S}$ & $176^{\circ} 38.48^{\prime} \mathrm{W}$ & 9540 & 369 & - \\
\hline K4 & $31^{\circ} 08.41^{\prime} \mathrm{S}$ & $176^{\circ} 48.48^{\prime} \mathrm{W}$ & 9300 & 393 & Lander \\
\hline K5 & $31^{\circ} 56.14^{\prime} \mathrm{S}$ & $177^{\circ} 17.48^{\prime} \mathrm{W}$ & 10,010 & 414 & - \\
\hline K6 & $32^{\circ} 08.93^{\prime} \mathrm{S}$ & $177^{\circ} 23.91^{\prime} \mathrm{W}$ & 9555 & 416 & MUC \\
\hline K7 & $32^{\circ} 11.22^{\prime} \mathrm{S}$ & $176^{\circ} 33.66^{\prime} \mathrm{W}$ & 6080 & 405 & $B C$ \\
\hline A2 & $21^{\circ} 46.86^{\prime} \mathrm{S}$ & $71^{\circ} 12.48^{\prime} \mathrm{W}$ & 7995 & 838 & MUC \\
\hline A3 & $23^{\circ} 02.94^{\prime} \mathrm{S}$ & $71^{\circ} 18.12^{\prime} \mathrm{W}$ & 7915 & 933 & MUC \\
\hline A4 & $23^{\circ} 21.78^{\prime} \mathrm{S}$ & $71^{\circ} 20.60^{\prime} \mathrm{W}$ & 8085 & 917 & MUC \\
\hline A5 & $23^{\circ} 49.02^{\prime} \mathrm{S}$ & $71^{\circ} 22.32^{\prime} \mathrm{W}$ & 7770 & 935 & MUC \\
\hline$A 6$ & $24^{\circ} 15.96^{\prime} \mathrm{S}$ & $71^{\circ} 25.38^{\prime} \mathrm{W}$ & 7720 & 846 & MUC \\
\hline A7 & $22^{\circ} 56.22^{\prime} \mathrm{S}$ & $71^{\circ} 37.08^{\prime} \mathrm{W}$ & 5500 & 843 & MUC \\
\hline A9 & $20^{\circ} 19.97^{\prime} \mathrm{S}$ & $70^{\circ} 58.70^{\prime} \mathrm{W}$ & 4050 & 938 & MUC \\
\hline A10 & $20^{\circ} 19.14^{\prime} \mathrm{S}$ & $71^{\circ} 17.46^{\prime} \mathrm{W}$ & 7770 & 838 & MUC \\
\hline
\end{tabular}

The average net primary production (NPP) was derived from the model of Behrenfeld and Falkowski 42 using remote sensing data from the period $2009-2018$ at the respective sites. The last column indicates the procedure that was applied for recovering sediment cores with intact sediment surfaces at the respective sites; autonomous lander (Lander), multi-corer (MUC), sub-sampling from boxcorer $(B C)$.

Table 2 Oxygen penetrations depth (OPD), diffusive $\mathrm{O}_{2}$ uptake (DOU), the relative amount of volume specific $\mathrm{O}_{2}$ consumption rate estimated to be associated with inorganic oxidation processes $\left(R_{\mathrm{ox}}\right)$, and the fraction of $\mathrm{O}_{2}$ microprofiles that were visually disturbed during the measurements.

\begin{tabular}{llllll} 
Site & Depth $(\mathbf{m})$ & OPD $(\mathbf{c m})$ & DOU ( $\left.\mathbf{~ m o l ~ m}^{-\mathbf{2}} \mathbf{d}^{-\mathbf{1}}\right)$ & $\boldsymbol{R}_{\mathbf{o x}}(\%)$ & Disturbed (\%) \\
\hline K2 & 9700 & $6.1 \pm 0.4$ & $668 \pm 83(5)$ & $23 \pm 5(4)$ & 17 \\
K3 & 9540 & $8.6 \pm 0.5$ & $538 \pm 91(7)$ & $13 \pm 8(6)$ & 13 \\
K4 & 9300 & $20.7^{\star}$ & $193 \pm 21(11)$ & $19 \pm 4(9)$ & 0 \\
K5 & 10010 & $8.9 \pm 0.1$ & $452 \pm 14(9)$ & $14 \pm 1(5)$ & 52 \\
K6 & 9555 & $11.5 \pm 0.3$ & $306 \pm 20(5)$ & $11 \pm 1(5)$ & 0 \\
K7 & 6080 & $26.4^{\star}$ & $152 \pm 22(8)$ & $5 \pm 3(5)$ & 0 \\
A2 & 7995 & $3.2 \pm 0.1$ & $1236 \pm 56(35)$ & $5 \pm 1(16)$ & 10 \\
A3 & 7915 & $2.6 \pm 0.1$ & $1793 \pm 77(29)$ & $4 \pm 1(13)$ & 6 \\
A4 & 8085 & $3.4 \pm 0.4$ & $1490 \pm 81(18)$ & $4 \pm 1(9)$ & 5 \\
A5 & 7770 & $4.0 \pm 0.2$ & $992 \pm 50(12)$ & $9 \pm 1(10)$ & 8 \\
A6 & 7720 & $4.1 \pm 0.3$ & $1035 \pm 143(8)$ & $6 \pm 1(8)$ & 0 \\
A7 & 5500 & $21.7^{\star \star}$ & $355 \pm 31(7)$ & $0 \pm 0(7)$ & 11 \\
A9 & 4050 & $6.2 \pm 0.5$ & $687 \pm 101(8)$ & $5 \pm 1(8)$ & 27 \\
A10 & 7770 & $3.1 \pm 0.3$ & $1634 \pm 71(19)$ & $8 \pm 1(12)$ & 5
\end{tabular}

Range indicates Standard Error and values in brackets indicate the number of observations. The * indicate values estimated from an empirical relation between DOU and OPD (Supplementary Fig. S2), while ${ }^{\star \star}$ imply that the value is based on only one observation, the remaining profiles at this site did not reach anoxia.

investigations in other oceanic realms have shown a general correlation between TOC availability at the sediment surface and benthic $\mathrm{O}_{2}$ consumption rates ${ }^{27}$. Unfortunately, we did not recover high quality sediment cores from all targeted sites, but for the available data the DOU correlated well to the TOC content of the sediment (Fig. 3a). This finding implies (i) that intensified organic matter deposition and benthic metabolism are general phenomena in hadal trench sediments relative to adjacent abyssal plains, and (ii) that spatial-temporal deposition dynamics above and within the hadal environment induce a large variation in biological and diagenetic activity along trench axes, and (iii) the intercept with the abscissa indicate a fraction of refractory organic carbon that does not contribute to the benthic $\mathrm{O}_{2}$ consumption.

Sediment deposition in hadal environments is strongly affected by mass-wasting events, and deposited organic carbon appears to include a large fraction of old and recalcitrant material with high terrigenous content $t^{5,7,28,29}$. However, the fact that we encountered elevated DOU rates in trench sediments implies that a fraction of the deposited organic matter has a relatively high lability, A number of processes could potentially facilitate the deposition of this material. Investigations in the Japan Trench shortly after the Tohoku-Oki Earthquake revealed hadal deposition of ${ }^{134} \mathrm{Cs}$ from the Fukushima nuclear powerplant and high loading of fresh organic material ${ }^{4}$. These observations suggest that seismic activity and tsunamis can translocate material including labile organic carbon from coastal oceans to the interiors of hadal trenches. Furthermore, mass mortality of faunal communities along trenches and on the trench slopes during mass wasting presumably led to intensified deposition of labile organic material along the trench axis ${ }^{4}$. Finally, tidal near-inertial fluid dynamics and complex bathymetry within trenches have been suggested to mediate focusing (and winnowing) of fresh material along trench axes ${ }^{6}$, and fresh phytodetrital material has been observed at great depth in hadal regions ${ }^{4}$. Thus, there are several potential pathways for deposition of labile organic material that could sustain elevated biological activity in trench sediments. The variation in DOU observed along the Kermadec and Atacama trench axes presumably reflects variable time since the last mass-wasting event or variations in recent material focusing along the axes. We have no direct way to quantify the lability of biologically processed material, but the DOU correlated well to the sedimentary content of Chlorophyll a (Fig. 3b), which is often 
$\left[\mathrm{O}_{2}\right]\left(\mu \mathrm{mol} \mathrm{L}{ }^{-1}\right)$
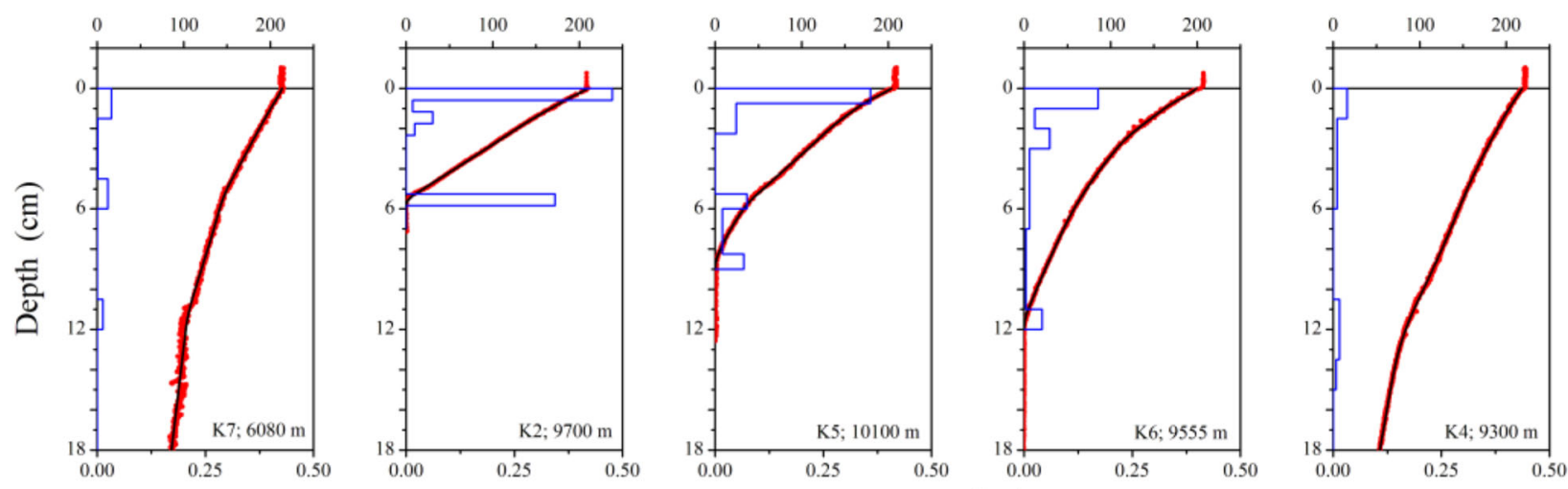

$\mathrm{O}_{2}$ consumption $\left(\mathrm{pmol} \mathrm{cm}^{-3} \mathrm{~s}^{-1}\right)$

\section{$\left[\mathrm{O}_{2}\right]\left(\mu \mathrm{mol} \mathrm{L}{ }^{-1}\right)$}
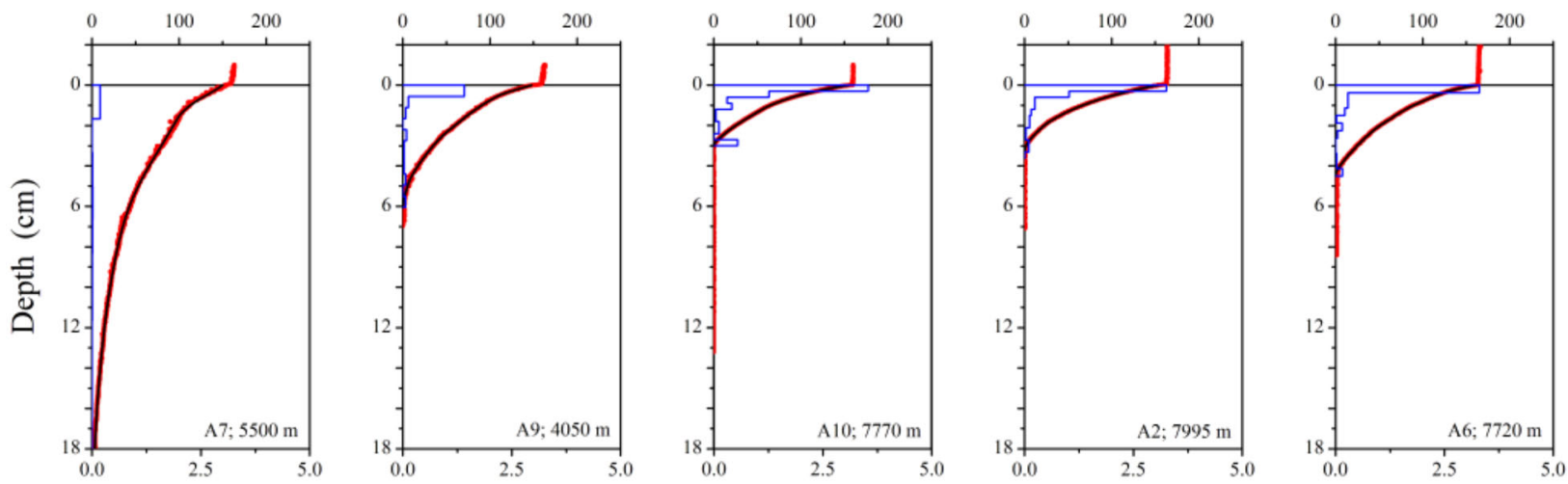

$\mathrm{O}_{2}$ consumption $\left(\mathrm{pmol} \mathrm{cm}^{-3} \mathrm{~s}^{-1}\right)$

Fig. 2 Selected oxygen microprofiles measured in the Kermadec Trench (K) and Atacama Trench (A) regions. The sites and water depth where the respective microprofiles were measured are indicated in each panel (see also Table 1). The depth distribution of the calculated volume specific $\mathrm{O}_{2}$ consumptions rates for each profile are depicted by blue lined boxes - note the different scale for profiles obtained in the two trenches. The estimated depth of the sediment surface is assigned to $0 \mathrm{~mm}$ and highlighted by a horizontal black line.
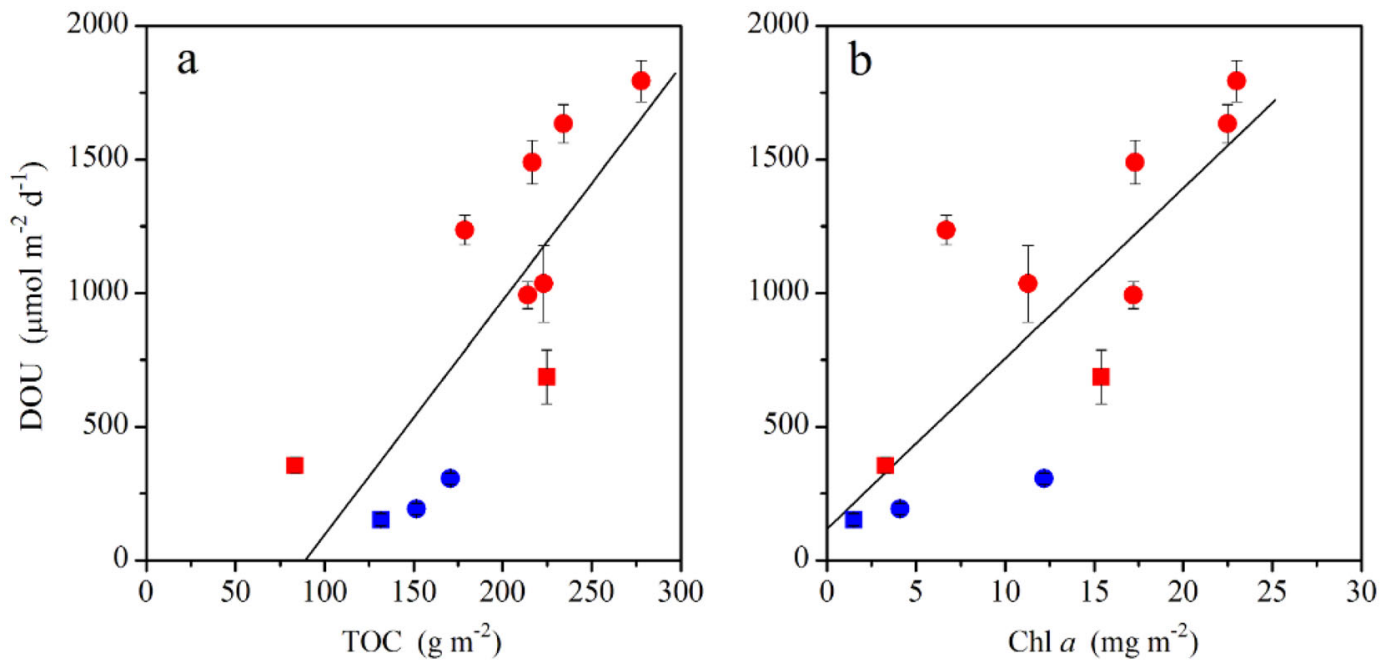

Fig. 3 The diffusive oxygen uptake (DOU) derived from in situ microprofiles. The profiles were measured by an autonomous benthic lander and plotted as a function of the total organic carbon content (TOC) (a), and chlorophyll a content ( $\mathrm{Chl} a)(\mathbf{b})$, both inventories were quantified in surface sediments $(0-5 \mathrm{~cm})$ of recovered intact sediment cores. Red and blue symbols depict values from the Atacama and Kermadec trench regions, respectively, where circles are values from the hadal depth range and squares represent values from abyssal reference sites (See Table 1), and error bars indicate standard error (Table 2). Data were approximated by linear regressions that provided the following equations DOU $=8.87 \mathrm{TOC}-432(R=0.81)$ and $\mathrm{DOU}=63.7$ $(\mathrm{Chl} a)+118(R=0.81)$ for $\mathbf{a}$ and $\mathbf{b}$, respectively. In some instances, the error bars are smaller than the symbol size. 


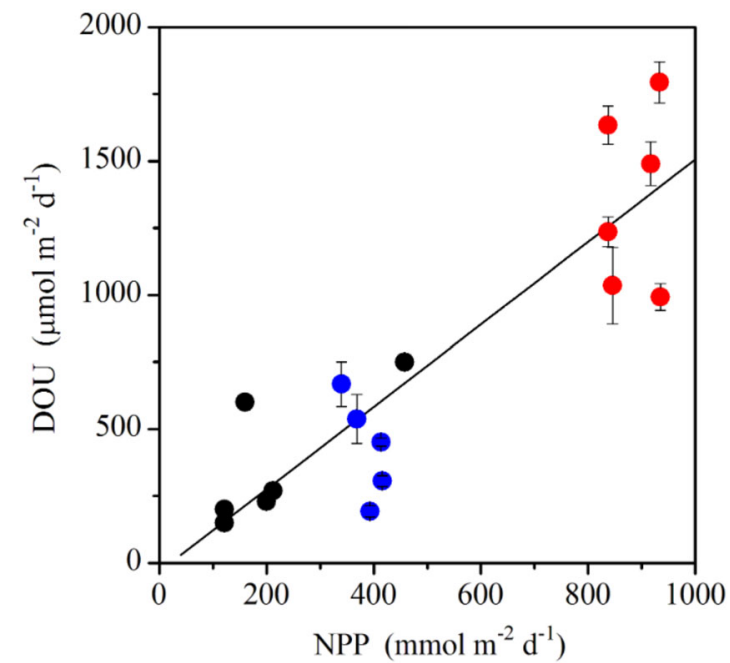

Fig. 4 In situ benthic oxygen uptake as a function of the estimated Net Primary Production (NPP). Black symbols represent values presented in Glud et al. ${ }^{13}$, Wenzhöfer et al. ${ }^{19}$, Luo et al. ${ }^{20}$ from the deepest sedimentary basins of the Mariana, Tonga, Izu-Bonin, Mussau, and New Britain trenches, respectively. Red and blue symbols depict values from the Atacama and Kermadec trenches of the present study, respectively. Error bars represent standard error, and the line, the linear regression of all data $Y=15.6 X-31.6$ $(R=0.89)$. In some instances, the error bars are smaller than the symbol size. NPP was derived by the model of Behrenfeld and Falkovski ${ }^{42}$ using remote sensin data from the period 2009-2018 at the respective sites. (e.g. Table 1).

used as an indicator of the availability of labile phytodetrital material ${ }^{30}$. This suggests that fluid dynamics and/or sorting during down-slope material transport might further amplify the delivery of relatively labile material to surface sediments at the trench axis.

A previous data compilation has suggested a close coupling between surface ocean productivity and hadal benthic $\mathrm{O}_{2}$ uptake rates $^{20}$ (Fig. 4). Indeed, measurements in the Atacama Trench that underlies a region of high ocean productivity, represent the highest recorded hadal DOU values to date, and these exceed on average the values from the Kermadec Trench by a factor of 3 (Fig. 4). However, the sites within the Kermadec Trench, which underlie a region of relatively low and evenly distributed ocean productivity (Table 1), show DOU levels that span the entire range of values recorded from previous studies compiled from five different Pacific trenches (Fig. 4). Thus, even though there is a connection between surface ocean productivity and benthic $\mathrm{O}_{2}$ consumption in hadal sediments, this linkage appears to be modulated by complex depositional processes.

Assuming a Respiratory Quotient of 1.0 (i.e., that $\mathrm{O}_{2}$ consumed via benthic diagenesis is balanced by a corresponding molar production of $\mathrm{CO}_{2}$ ), our compilation implies that-on averagebenthic mineralization of organic material in hadal settings corresponds to $1.6 \%$ of the estimated overlying surface production (Fig. 4). This estimate of benthic mineralization is about 1.5-2.0 times higher than the estimated total depositional flux of organic material at these depths as derived from empirical relations between surface production and material collected by sediment traps ${ }^{31-33}$. As this vertical depositional flux will include a considerable fraction of highly refractory material with little or no nutritional value, this calculation further underscores that hadal trenches in general act as deep sea depocenters, where lateral inputs of reactive organic matter enhance benthic metabolic and diagenetic processes to such an extent that these environments stand out as hotspots in the deep sea.

Benthic $\mathrm{O}_{2}$ consumption is generally accepted as a robust proxy for the total benthic mineralization of organic carbon ${ }^{34,35}$. However, the basic underlying assumption of efficient oxygenic reoxidation of reduced equivalents from anaerobic mineralization might be compromised in the unique depositional environments of hadal trenches. Lack of efficient bioturbation at hadal depths and deposition of labile material in anoxic sediment layers during recurring mass wasting events may lead to burial of reduced equivalents from anaerobic degradation. While the $30 \mathrm{~cm}$ long sediment cores recovered from the Kermadec trench axis were relatively oxidized with low content of iron-sulfides, the sediment from the Atacama trench appeared highly reduced (Thamdrup et al. in prog). Onboard incubations with ${ }^{35} \mathrm{SO}_{4}{ }^{2-}$ documented active sulfate reduction below the nitrogenous horizon and the deeper sediment had variable but generally increasing levels of ferrous iron and iron sulfides. On average, the total reducible inorganic sulfur content amounted to $11 \pm 9 \mu \mathrm{mol} \mathrm{cm}{ }^{-3}$, while the average $\mathrm{HCl}$ extractable $\mathrm{Fe}(\mathrm{II})$ content was $70 \pm 17 \mu \mathrm{mol} \mathrm{cm}^{-3}$ at sediment depths from $20-30 \mathrm{~cm}$ (Assuming aerobic oxidation stoichiometry this corresponds to $39 \pm 16 \mu \mathrm{mol} \mathrm{cm}^{-3}$ of $\mathrm{O}_{2}$ equivalents buried in these largely non-bioturbated sediments. Thus, even though our $\mathrm{O}_{2}$ microprofiles indicate some degree of inorganic reoxidation at the oxic-anoxic interface (Fig. 2 and Table 2), the benthic $\mathrm{O}_{2}$ consumption may underestimate the total benthic carbon mineralization in hadal settings. In addition, although it should be minor, a contribution from macrofauna is not included in our current assessment. Therefore, our estimates of $\sim 3-5$ times higher carbon mineralization rates in hadal settings as compared to adjacent abyssal sites should be regarded as conservative minimum values-and hadal carbon mineralization might be even more important than our assessment suggests. Future work on anaerobic processing of organic material in hadal sediments is required to resolve this issue.

This study documents that the biogeochemical function of hadal trenches cannot be understood by extrapolating findings from other oceanic realms. The trenches generally act as depocenters for organic material and express intensified early diagenetic activity. However, we also demonstrate extensive variations in benthic activity both between and along the axis of the two studied trenches. Hadal benthic activity is linked to the regional surface production, but activity levels are strongly modulated by complex local deposition dynamics. Hadal trench environments therefore appear to be much more dynamic and biogeochemically diverse than previously recognized. This spatial and temporal variation needs to be fully appreciated for understanding and quantifying the biogeochemical function and importance of hadal trench environments, and to resolve linkages to small and large scale hadal biogeographic patterns.

\section{Methods summary}

Before initiating work at each site, one of two free-fall camera lander systems, "Reivers", was used to inspect sediment conditions. When deployed, these vehicles descended to the seafloor at $47 \mathrm{~m} \mathrm{~min}^{-1}$ and filmed the penetration of a vertical $7.5 \mathrm{~cm}$ diameter $\times 100 \mathrm{~cm}$ steel bar in the sediment upon landing. The bar had markings at $10 \mathrm{~cm}$ intervals and was part of a two-part ballast system (the other being a $56 \mathrm{~kg}$ stack of steel plates), that was jettisoned by acoustic command from the ship shortly after landing. Ballast release was actuated by a single Oceano 2500 Ultimate Depth Acoustic Release (IXSEA Blue, France) via a shipside telecommand unit (TT801, IXSEA Blue France). Bespoke HDTV video cameras (GZ-V950, JVC Kenwood) were mounted in stainless steel pressure housings, with sapphire viewports and 
custom-built pressure-stable LED arrays were used as light source. Video and pressure data were downloaded upon retrieval of the vehicles whereby sediment conditions and bar penetration could be assessed. Sediment penetration of the bar enabled us to optimize buoyancy and ballast for other lander instruments and sediment samplers, and in one case to abandon any further benthic work due to rocky outcrops (Supplementary Fig. S1).

The autonomous free-fall Hadal-Profiler Lander was slightly modified from a previous description ${ }^{13,22}$. In short, once landed the profiler instrumentation was programmed to wait for $1-2 \mathrm{~h}$ before it lowered stepwise an array of 5 to $9 \mathrm{O}_{2}$ microelectrodes at a depth resolution of 100-200 $\mu \mathrm{m}$; this enabled us to resolve detailed concentration profiles within the diffusive boundary layer (DBL) and throughout the oxic zone. At each depth the microelectrodes rested for $5 \mathrm{~s}$ to equilibrate with the pore water $\mathrm{O}_{2}$ concentration before reading. After reaching $\sim 15-20 \mathrm{~cm}$ of sediment depth, the sensors retracted to the start position and were then moved horizontally by $10-15 \mathrm{~cm}$ before repeating the measuring routine. Thereby, several $\mathrm{O}_{2}$ microprofiles were obtained within a $90 \times 15 \mathrm{~cm}$ sediment area during the 15-24hour long deployments. The microelectrodes were of the "Clarktype" and equipped with a guard cathode ${ }^{36}$. Sensors were linearly calibrated against signals in the bottom water of known $\mathrm{O}_{2}$ concentration as determined by Winkler titration on recovered bottom water and constant low signals in presumed anoxic sediment layers. These signals were compared to on-board signals recorded in anoxic, dithionite-spiked bottom water prior to instrument deployments. In cases when sensors did not reach anoxic sediment layers (Site K4, K7, A7), the onboard "zero" values were used for calibration. For all profiles, the DOU was determined from the $\mathrm{O}_{2}$ concentration gradient within the DBL and the molecular diffusion coefficient for $\mathrm{O}_{2}$ at the given salinity and temperature ${ }^{37}$. For a subset of profiles (Table 2), volume specific $\mathrm{O}_{2}$ consumption rates $\left(R_{\mathrm{vol}}\right)$ were derived as a function of sediment depth from the $\mathrm{O}_{2}$ concentration profile, tortuosity corrected molecular diffusion coefficient, and measured porosity $^{38}$ assuming Fickian steady-state diffusion using the profile interpretation software, PROFILE ${ }^{23}$. For these calculations, porosity profiles were established by linear interpolation of discreet values obtained in recovered sediment cores (see below). As shown in previous studies, the DOU derived from the DBLapproach and by depth-integrating the $\mathrm{R}_{\mathrm{vol}}$ values provided similar estimates of oxygen consumption ${ }^{15}$.

Sediment was mainly recovered by a multi-corer ${ }^{24}$, but occasionally we had more success using either a box corer (BC) or an autonomous lander system for core recovery (Table 2). Recovered sediment cores were immediately transferred to an onboard thermoregulated laboratory that maintained ambient temperature close to bottom water values $\left(2-4^{\circ} \mathrm{C}\right)$. For sediment recovered in the Kermadec region, sediment was sectioned in $1 \mathrm{~cm}$ slices down to $2 \mathrm{~cm}$ depth, $2 \mathrm{~cm}$ slices to $10 \mathrm{~cm}$ and subsequently in $5 \mathrm{~cm}$ slices to the core bottom. For the sediment recovered in the Atacama region, sediment was sectioned in $1 \mathrm{~cm}$ slices down to $10 \mathrm{~cm}, 2.5 \mathrm{~cm}$ slices to $20 \mathrm{~cm}$, followed by $5 \mathrm{~cm}$ slices until the bottom of the core. Samples were homogenized in plastic bags and stored at $-20^{\circ} \mathrm{C}$ until laboratory analysis onshore.

Sediment porosity was determined from the measured wet density and weight loss after $24 \mathrm{~h}$ of drying at $60^{\circ} \mathrm{C}$. The total organic carbon content (TOC wt.\%) was quantified using $50 \mathrm{mg}$ of freeze-dried, ground sediment using the anhydrous pyrolysis Hawk (Wildcat Technologies), based on the Rock-Eval 6 method ${ }^{39}$. The TOC was converted to volume specific weight from the measured sediment density. The accuracy and precision of these measurements were better than $5 \%$ based on analysis of duplicates and standard reference materials (WT10, IFP160000). Chl $a$ samples were measured in acetone (90\%, vol:vol)-extracted subsamples using a Turner fluorometer ${ }^{40}$. Both TOC and Chl a were converted to sediment inventories by depth integrating to a sediment depth of $5.0 \mathrm{~cm}$.

\section{Data availability}

The datasets generated and/or analyzed during the current study are available from the corresponding author (R.N.G.) on request and will be made available in the PANGAEA repository under the project title "HADES- ERC" (www.pangaea.de).

Received: 23 June 2020; Accepted: 18 December 2020; Published online: 29 January 2021

\section{References}

1. Jamieson, A. (ed.). The Hadal Zone-life in the deepest ocean. Cambridge p. 372 (Cambridge University Press, Cambridge, 2015).

2. Jamieson, A. J. Ecology of the deep oceans: hadal trenches. In eLS. (John Wiley \& Sons, Ltd, Chichester, 2011).

3. Itou, M., Matsumura, I. \& Noriki, S. A large flux of particulate matter in the deep Japan Trench observed just after the 1994 Sanriku-Oki earthquake. DeepSea Res. 47, 1987-1998 (2000).

4. Oguri, K. et al. Disturbance in the Japan Trench as induced by the 2011 Tohoku-Oki Earthquake. Sci. Rep. 3, 1915 (2013).

5. Bao, R. et al. Tectonically-triggered sediment and carbon export to the Hadal zone. Nat. Commun 9, 121 (2018).

6. Turnewisch, R. et al. Recent sediment dynamics in hadal trenches: evidence for the influence of higher frequency (tidal, near-intertidal) fluid dynamics. Deep-Sea Res. 49, 1255-1481 (2014).

7. Kioka, A. et al. Megathrust earthquake drives drastic organic carbon supply to the hadal trench. Nat. Commun. 9, 1553 (2019).

8. Jumars, P. A. \& Hessler, R. R. Hadal community structure: implications from the Aleutian Trench. J. Mar. Res. 34, 547-560 (1976).

9. Danovaro, R., Croce, N. D., Dell'Anno, A. \& Pusceddu, A. A depocenter of organic matter at $7800 \mathrm{~m}$ depth in the SE Pacific Ocean. Deep-Sea Res. I 50 1411-1420 (2003).

10. Belyaev, G. M. Deep sea ocean trenches and their fauna. Nauka Publishing House, Moscow, p. 385 (Translated to English by Scripps Institution of Oceanography, USA, 2004).

11. Tietjen, J. H., Deming, J. W., Rowe, G. T., Macno, S. \& Wilke, R. J. Meiobenthos of the Hatteras abyssal-plain and Puerto-Rico trenchabundance, biomass and association with bacteria and particulate fluxes. Deep-Sea Res. 36, 1567-1577 (1989).

12. Blankenship, L. E., Yayanos, A. A., Cadien, D. B. \& Levin, L. A. Vertical zonation patterns of scavenging amphipods from Hadal zone of Tonga and Kermadec trenches. Mar. Technol. Soc. J. 43, 137-143 (2006).

13. Glud, R. N. et al. High rates of microbial carbon turnover in sediments in the deepest oceanic trench on Earth. Nat. Geosci. 6, 284-288 (2013).

14. Manea, E. et al. Viral infections boost prokaryotic biomass production and organic C Cycling in Hadal trench sediments. Front. Microbiol. 10, 1-11 (2019).

15. Glud, R. N., Gundersen, J. K., Jørgensen, B. B., Revsbech, N. P. \& Schulz, H. D. Diffusive and total oxygen uptake of deep sea sediments in the eastern South Atlantic Ocean: in situ and laboratory measurements. Deep-Sea Res. 41, 1767-1788 (1994)

16. Glud, R. N., Gundersen, J. K. \& Holby, O. Benthic in situ respiration in the upwelling area off central Chile. Mar. Ecol. Prog. Ser. 186, 9-18 (1999).

17. Hall, P. O. J. et al. Dissolved organic matter in abyssal sediments; core recovery artefacts. Limnol. Oceanogr. 52, 19-31 (2007).

18. Glud, R. N. Oxygen dynamics of marine sediments. Mar. Biol. Res. 4, 243-289 (2008).

19. Wenzhöfer, F. et al. Benthic carbon mineralization in hadal trenches: assessment by in situ $\mathrm{O}_{2}$ microprofile measurements. Deep-Sea Res. 116, 279-286 (2016).

20. Luo, M. et al. Benthic carbon mineralization in hadal trenches: insights from in situ determination of benthic oxygen consumption. Geophys. Res. Lett. 45, 2752-2760 (2018)

21. Stewart, H. A. \& Jamieson, A. J. Habitat heterogeneity of hadal trenches: considerations and implications for future studies. Progr. In Oceanogr. 161, 47-65 (2018).

22. Glud, R. N. et al. In Situ microscale variation in distribution and consumption of $\mathrm{O}_{2}$ : a case study from a deep ocean margin sediment. Limnol. Oceanogr. 54, 1-12 (2009).

23. Berg, P., Risgaard-Petersen, N. \& Rysgaard, S. Interpretation of measured concentration profiles in sediment pore water. Limnol. Oceanogr. 43, 1500-1510 (1998). 
24. Barnett, P. R. O., Watson, J. \& Connelly, D. A multiple corer for talking virtually undisturbed samples from shelf, bathyal and abyssal sediments. Oceanol. Acta. 7, 399-408 (1984).

25. Hessler, R. R. \& Jumars, P. A. Abyssal community analysis from replicate box cores in the central North Pacific. Deep-Sea Res. 21, 185-209 (1974).

26. Canfield, D.E. Organic matter oxidation in marine sediments. In Wollast, R.F., Mackenzie T., Chou L. (Eds). Interactions of C, N, P, and S biogeochemical cycles and global change. Berlin: Springer-Verlag, 333-363 (1994).

27. Cai, W. J. \& Reimers, C. E. Benthic oxygen concentration and core top organic carbon content in the dee northeast Pacific Ocean. Deep-Sea Res. 42, 1681-1699 (1995).

28. Xiao, W. et al. Predominance of hexamethylated 6-methyl branched glycerol dialkyl glycerol tetraethers in the Mariana Trench: source and environmental implication. Biogeoscience. 17, 2135-2148 (2020).

29. McHugh, C. M. et al. Remobilization of the surficial sediment triggered be A. D. $2011 \mathrm{Mw} 9$ Tohoku-Oki earthquake and tsunami along the Japan Trench. Geology 44, 391-394 (2016).

30. Stephens, M. P., Kadko, D. C., Smith, C. R. \& Latasa, M. Chlorophyll a and pheopigments as tracers of labile organic carbon at the central equatorial Pacific seafloor. Geochim Comochim Acta 61, 4606-4619 (1997).

31. Berger, W. H., Fisher, K., Lai, C., \& Wu, G. Ocean carbon flux: global maps of primary production and export production in Biogeochemical cycling and fluxes between the deep euphotic zone and other realms. (Agegian, C. R. ed.) p. 131-176 (NOAA Undersea Res. Prog. Silver Spring, MD, 1988).

32. Jahnke, R. A. The global ocean flux of particulate carbon: areal distribution and magnitude. Glo. Biochem. Cycl. 10, 71-88 (1996).

33. Suess, E. Particulate organic carbon flux in the oceans-surface productivity and oxygen utilization. Nature 288, 260-263 (1980).

34. Canfield, D. E. et al. Pathways of organic carbon oxidation in three continental margin sediments. Mar Geo 113, 27-40 (1993).

35. Thamdrup, B. \& Canfield, D.E. Benthic respiration in aquatic sediments. Sala, O., Mooney, H., Jackson, R., Howarth, R. (eds) Methods In ecosyst. Science Springer, New York (2000).

36. Revsbech, N. P. An oxygen microelectrode with a guard cathode. Limnol Oceanogr. 34, 474-478 (1989).

37. Jørgensen, B. B. \& Revsbech, N. P. Diffusive boundary layers and the oxygen uptake of sediment and detritus. Limnol. Oceanogr. 30, 111-122 (1985).

38. Ullmann, W. J. \& Aller, R. C. Diffusion coefficients in nearshore marine sediments. Limnol. Oceanogr. 27, 552-557 (1982).

39. Carrie, J., Sanei, H. \& Stern, G. Standardization of Rock-Eval pyrolyses for the analysis of recent sediments and soils. Org. Geochem. 46, 38-53 (2012).

40. Shuman, F. R. \& Lorenzen, C. J. Quantitative degradation of chlorophyll by marine herbivore ${ }^{1}$. Limnol. Oceanogr. 7, 580-586 (1975).

41. Ryan, W. B. F. et al. Global multi-resolution topography synthesis. Geochem. Geophys. Geosyst. 10, Q03014 (2009).

42. Behrenfeld, M. J. \& Falkowski, P. G. Photosynthetic rates derived from satellite-based chlorophyl concentration. Limnol. Oceanogra 42, 1-20 (1997).

\section{Acknowledgements}

We would like to thank the captains, crews and scientific personnel of the $R V$ Tangaroa (TAN1711; 24.11.-14.12.2017) and RV Sonne (SO261; 02.03.-02.04.2018). Ship time for RV Tangaroa was funded by the HADES-ERC Advanced grant "Benthic diagenesis and microbiology of hadal trenches" \#669947 and Coasts \& Oceans Centre of New Zealand's National Institute of Water \& Atmospheric Research (NIWA, New Zealand), while ship time for RV Sonne was provided by BMBF (Germany). The study was financially supported by the HADES-ERC Advanced grant "Benthic diagenesis and microbiology of hadal trenches" \#669947, and by the Max Planck Society. Furthermore, we would like to thank Johannes Lemburg, Per Martensen, Diana Macpherson, Mathias Zabel, Axel Nordhausen and Volker Asendorf for technical assistance, and Matt Pinkerton (NIWA, New Zealand) for deriving NPP data from Behrenfeld and Falkowski ${ }^{42}$ The manuscript was greatly improved by accommodating suggestion from three reviewers.

\section{Author contributions}

R.N.G. wrote the manuscript with contributions from all co-authors. R.N.G., P.B., F.W A.G., B.T., H.A.S., A.J.J., K.O., and H.S, carried out the measurements, performed the analytical work and the theoretical analyses. F.W., A.R., R.N.G. M.L., and A.G. organized the expeditions and logistics, and assisted in the sampling. All authors discussed the results, their implications and commented on the manuscript as it progressed.

\section{Competing interests}

The authors declare no competing interests.

\section{Additional information}

Supplementary information is available for this paper at https://doi.org/10.1038/s43247020-00087-2.

Correspondence and requests for materials should be addressed to R.N.G.

Peer review information Primary handling editors: Mojtaba Fakhraee, Joe Aslin

Reprints and permission information is available at http://www.nature.com/reprints

Publisher's note Springer Nature remains neutral with regard to jurisdictional claims in published maps and institutional affiliations.

(c) (i) Open Access This article is licensed under a Creative Commons Attribution 4.0 International License, which permits use, sharing, adaptation, distribution and reproduction in any medium or format, as long as you give appropriate credit to the original author(s) and the source, provide a link to the Creative Commons license, and indicate if changes were made. The images or other third party material in this article are included in the article's Creative Commons license, unless indicated otherwise in a credit line to the material. If material is not included in the article's Creative Commons license and your intended use is not permitted by statutory regulation or exceeds the permitted use, you will need to obtain permission directly from the copyright holder. To view a copy of this license, visit http://creativecommons.org/ licenses/by/4.0/

(C) The Author(s) 2021 